\title{
Teacher Needs Analysis on the Development of Android-Based Chemistry Learning Media
}

\author{
Nurlaelah $^{1, *}$ Endang Widjajanti Laksono ${ }^{2}$ \\ ${ }^{1}$ Master of Chemistry Education, Faculty of Mathematics and Natural Sciences, Universitas Negeri Yogyakarta, \\ Indonesia \\ ${ }^{2}$ Department of Chemistry Education, Faculty of Mathematics and Natural Sciences, Universitas Negeri \\ Yogyakarta, Indonesia \\ *Corresponding author. Email: nurlaelah.2019@student.uny.ac.id
}

\begin{abstract}
Chemistry is an abstract knowledge, so it requires media as an intermediary in delivering the material. In supporting this, an analysis of teacher needs is carried out. This study aimed to describe the teacher's need for Android-based chemistry learning media that can support the chemistry learning process in the classroom. The method used in this research is survey method. The research participants were 10 chemistry teachers from schools in Makassar City. Data collection was carried out by means of a questionnaire (google form) which is the questionnaire adapted from the results of research journals relevant to the development of chemistry learning media. The results were analyzed descriptively and obtained data that the media often used by teachers, such as PPT/LCD projectors with a percentage of $90 \%$, while android based chemistry learning media is still very rarely used. The obstacles were making, using and developing media which taken a very long time so that the teachers feel uninterested in making media and there is a lack of ideas on what media is good for learning chemistry. So they suggested that tutorials be given in the creating and use of instructional media.
\end{abstract}

Keywords: Needs analysis, Learning media, Android.

\section{INTRODUCTION}

Recognizing chemistry as an abstract knowledge makes many students think of chemistry is a difficult subject because it requires imagination to understand the concept [1]. Especially in schools, chemistry learning is still carried out conventionally because it is only designed with reference to the content or material content without considering the cognitive demands, attitudes and skills that students must have [2]. Whereas understanding chemistry depends on things that are not seen and untouched [3]. There are four levels of understanding, they are macroscopic, microscopic, symbolic, and process. Another opinion is understanding chemistry as a complex subject makes students experience the difficulty in visualizing microscopic (abstract) phenomena because this microcomplexity is inherent in the nature of chemical concepts which requires combining several tools in representing concepts and also increasing students' conceptual understanding [4]. For this reason, not only a learning model is needed but the media is also very important as a tool that will help students understand chemistry at various levels.
One of the materials taught in SMA/MA is acid and base topic. Acid-base is the main topic that students learnt in class XI. Acid-base material was chosen because the chemical properties of acid-base is often found in everyday life where there is often misunderstanding of concepts (misconceptions) so it is important to study that topic [5]. Going along with the development of technology in the current century, it has developed very rapidly, making various types of technology appear with different purposes and uses. One of them is used in the world of education, especially during the learning process [6].

The use of technology in the learning process can be implemented through technology-based learning media. However, there are still many educators who are constrained in implementing technology-based learning. As an example, teachers' mastery of technology is still minimum, school facilities are not supportive, teaching schedules are tight, and internet connection is not sufficient [7]. Even though the learning media in the form of an Android application is a learning media that is easy to use and practice. The combination of images, text, colors and videos as well 
as animation in the learning material will make students interested in reading and studying it.

Based on the research results, it shows that the development of media has a positive impact in increasing learning outcomes and improving the quality of learning [8]. Learning media can be realized in the form of an android application [9]. Android is a solution to face educational challenges [10]. This is also in line with the results of research which states that mobile learning can improve learning outcomes because mobile learning allows students to access lessons and assignments anywhere and anytime. Meanwhile, for teachers, mobile learning can help upload teaching materials, determine discussions and receive student assignments electronically [11]. Based on the results of observations of class XI MIA students of SMAN 11 Makassar, it was found that all students had androids. Seeing this potential, the appropriate media used by teachers to carry out interesting, fun learning and make students more active is media that uses Android. This is why this research is needed.

The purpose of this study is to review what learning media are used in chemistry learning and what factors prevent teachers from making and using instructional media in a school environment located in Makassar City, South Sulawesi Province at the Senior High School level.

\section{RESEARCH METHODS}

This research was a qualitative descriptive study. In this study, an analysis of the needs of instructional media was carried out. The analysis was carried out as a whole regarding the use of learning media in the selected schools. The subjects in this study involved 10 class XI chemistry subject teachers from various schools in Makassar City. The school was selected by purposive sampling because these teachers were prepared to become facilitators in carrying out Table 1. Analysis of teacher needs on the development of android-based learning media

\begin{tabular}{|c|c|c|c|}
\hline No. & Questions (Aspect) & Response & Percentage \\
\hline 1. & Types of media that are often used & $\begin{array}{l}\text { Study CD/video } \\
\text { PPT/LCD Projector } \\
\text { Learning games } \\
\text { Android } \\
\text { Microsoft Teams }\end{array}$ & \begin{tabular}{l|}
$80 \%$ \\
$90 \%$ \\
$40 \%$ \\
$20 \%$ \\
$40 \%$
\end{tabular} \\
\hline 2. & Frequency of use of media & $\begin{array}{l}\text { Yes } \\
\text { No }\end{array}$ & $\begin{array}{c}100 \% \\
0 \%\end{array}$ \\
\hline 3. & $\begin{array}{l}\text { The advantages and disadvantages of media } \\
\text { There is a simulation }\end{array}$ & Yes & $70 \%$ \\
\hline
\end{tabular}

chemistry learning activities in class XI from a predetermined population. The data was taken by using an online questionnaire about the condition of the learning media in the school. The research instrument in the form of a questionnaire (google form) was adapted from the results of research journals relevant to the development of chemistry learning media [12]. From the results of the study, a questionnaire was also made with regard to several aspects consisting of (1) the type of learning media commonly used; (2) Frequency of media used; (3) Strengths and weaknesses of commonly learning media used; (4) Teachers' constraints in making learning media and (5) Solutions that should be done to overcome these obstacles. These five aspects were used because they were considered to be the main aspects that need to be observed in implementing the use of chemistry learning media and the environment in schools. The questionnaire made has been validated by experts who are competent in their fields. The questionnaire result data is presented in the form of a percentage of teachers who answered "yes" and "no" to each question and then analyzed to determine the teacher's needs for Android-based chemistry learning media.

\section{RESULT AND DISCUSSION}

The distribution of questionnaires carried out to teachers is the initial stage of a series of development researches to determine the needs of teachers in supporting the chemistry learning process in the classroom. The results of this needs questionnaire are then used as the basis for developing learning media in the form of android-based applications. This application acts as a media that will help teachers and students during the learning process of chemistry, especially in acid and alkaline solutions. Based on the questionnaire, data were obtained as follows. 


\begin{tabular}{|l|l|l|c|}
\hline No. & Questions (Aspect) & Response & Percentage \\
\hline \multirow{4}{*}{} & Easy & No & $70 \%$ \\
& Supports learning & No & $80 \%$ \\
& Never received a media creation tutorial & No & $60 \%$ \\
\hline \multirow{2}{*}{ H. } & Teave created their own media & No & $80 \%$ \\
\hline & Understanding of the media is lacking & Yes & $100 \%$ \\
& Lack of supporting facilities & No & $70 \%$ \\
& Have no ideas & Yes & $60 \%$ \\
& Takes a long time & Yes & $90 \%$ \\
& Less attractive & Yes & $80 \%$ \\
& Lack of knowledge about media development & Yes & $100 \%$ \\
\hline 5. & Solutions to overcome teacher constraints & & $100 \%$ \\
& Provide tutorials for making media & Yes & $100 \%$ \\
& Provide tutorials on developing media & Yes & $100 \%$ \\
& Provide tutorials using media & Yes & $100 \%$ \\
\hline
\end{tabular}

Based on Table 1, there is a difference in the percentage for each type of media used in chemistry learning in schools. This table also explains the highest percentage of "yes" and "no" answers for each question. The results of the analysis of the types of media that are often used can be seen in Figure 1. Observing from the aspect of the type of media that was often used, data was obtained that the PPT/LCD media projector was the most frequently used media seen from the overall percentage of $33 \%$ as many as 9 teachers, followed by other media such as learning $\mathrm{CD} /$ Videos with a percentage of $30 \%$ as many as 8 teachers, learning games and Microsoft Teams at $15 \%$ as many as 4 teachers while Android is very rarely used with only $7 \%$ or one teacher. This is because PPT/LCD was the only media provided by schools and for Android media, most schools had never used it as a learning media. In addition, PPT / LCD media are good intermediaries in conveying material to students [13]. The second aspect regarding the frequency of that media usage is often used in the learning process of chemistry in schools because to teach chemistry you have to go through an intermediary (learning media) and the percentage was seen as high as $100 \%$. This shows that all teachers have used learning media in chemistry. Apart from its availability, the media is also able to increase students' abstract understanding in learning [14].

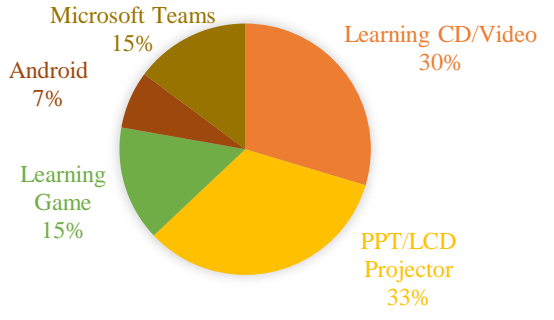

Figure 1 Results of analysis of media types used

Based on the aspects of the advantages and disadvantages of using that media, data was obtained that the media that is often used in schools makes learning easier because there were some teachers who have already received tutorials from using the media, but there were also some teachers who have difficulty using the media, especially in making learning media by themselves. This can be seen from the percentage of $17 \%$ ( 3 teachers) said that the use of media in learning chemistry is quite easy, as many as $11 \%$ (2 teachers) have made their own learning media, as many as $22 \%$ (4 teachers) have received tutorials and as many as $39 \%$ (4 people) said that the media that have ever been made contain only animation. The results of the analysis for the advantages and disadvantages of the media was shown in Figure 3. The obstacles faced by the teacher aware the lack of understanding in making and developing media seen 
from the percentage, which is $20 \%$, then the lack of supporting facilities is $14 \%$ and they do not have ideas or mastery the technology, especially Android as a learning media with a percentage of $20 \%$ and it takes time.

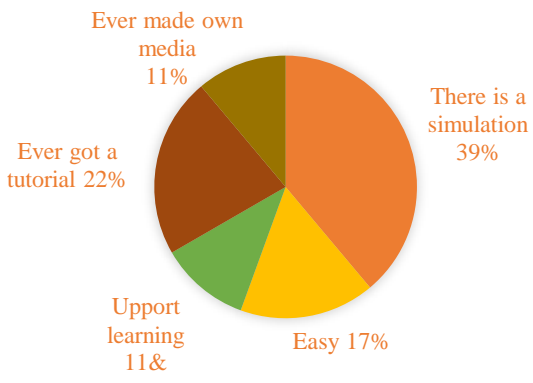

Figure 2 Results of the media advantage and disadvantage analysis

Time in making and using learning media with a percentage of $18 \%$. For the results of the analysis of the constraints faced by the teacher can be seen in Figure 4.

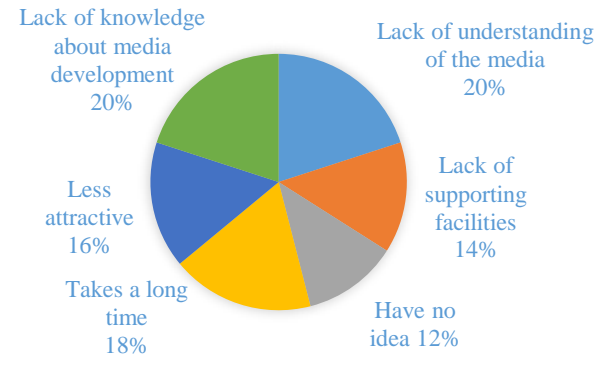

Figure 3 Teacher constraints in making media

The solution to this problem is that the teachers want a tutorial in making, developing and using chemistry learning media so that they will be able to make their own media which can be seen from the percentage of $25 \%$. This is related with many teachers who have not been able to integrate technology with the learning process to be used as a media. In addition, there were several factors that hinder the use of technology in learning such as teachers feel burdened because they are required to be more creative, require careful preparation and also require the ability to operate the technology [11]. As for the aspect of the solution expected by the teacher, it can be cleared in Figure 5. As for the response given by the teacher to the development of Android-based learning media as a reference or media in chemistry learning, it can be concluded that the teacher gave responds very well and agreed with the development of Android-based chemistry learning media because innovative learning media is able to make students interested in studying chemistry.

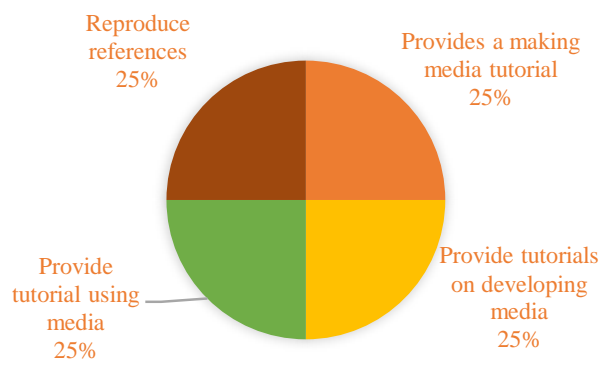

Figure 4 The solution expected by the teacher

\section{CONCLUSION}

Based on the results of the analysis of teacher needs as the basis things for developing chemistry learning media based on android, it can be concluded that the media most often used in the learning process is PPT/LCD projectors, while android is rarely used as a learning media. The obstacles for teachers in using the media are due to the lack of supporting facilities, lack of understanding in the producing, developing and using the media.

\section{REFERENCES}

[1] M. Jannah, J. Copriady, Rasmiwetti, Development of Interactive Learning Media Using Autoplay Media Studio 8 for Colloidal Chemistry Material, Journal of Educational Sciences 3(1) (2019) 132-144. DOI: http://dx.doi.org/10.31258/jes.3.1.p.132-144

[2] M. Hugerat, N. Kortam, Improving Higher Order Thinking Skills Among Freshmen by Teaching Science Through Inquiry, Eurasia Journal of Mathematics, Science and Technology Education 10(5) (2014) 447-454. DOI: https://doi.org/10.12973/eurasia.2014.1107a

[3] M. Barak, R. Hussein-Farraj, Integrating ModelBased Learning and Animations for Enhancing Students' Understanding of Proteins Structure and Function, Research in Science Education 43(2) (2013) 619-636. DOI: https://doi.org/10.1007/s11165-012-9280-7

[4] S. Cai, X. Wang, F. Chiang, A Case Study of Augmented Reality Simulation System Application in A Chemistry Course, Computers in Human Behavior 37(3) (2014) 31-40. DOI: https://doi.org/10.1016/j.chb.2014.04.018

[5] S. Rahayu, A. Chandrasegaran, D.F. Treagust, M. Kita, S. Ibnu, Understanding Acid-Base Concepts: Evaluating The Efficacy of A Senior 
High School Student-Centred Instructional Program in Indonesia, International Journal of Science and Mathematics Education 9(6) (2011) 1439-1458. DOI: https://doi.org/10.1007/s10763-010-9272-x

[6] N. Özdener, F. Demirci, Determining Students' Views About an Educational Game-Based Mobile Application Supported with Sensors, Technology Knowledge and Learning 24(1) (2019) 143-159. DOI: https://doi.org/10.1007/s10758-018-9368-X

[7] M. Grosch, R. Berger, G. Gidion, M. Romeo, Which media services do students use in fact? Results of an international empirical survey, in: Procedia-Social and Behavioral Sciences, vol. 141, Elsevier, Amsterdam, 2014, pp. 795-806. DOI: https://doi.org/10.1016/j.sbspro.2014.05.139

[8] K. Ekawarna, A. Rachman, Firman, Development of multimedia Learning Economic Models to Improve Student Learning Outcome, Journal of Research \& Method in Education 6(6) (2016) 47-54. DOI: https://doi.org/10.9790/7388-0606074754

[9] C. Onyenemezu , E.S. Olumati, Educational Media and Technology: A Panacea for Effective Teaching and Learning Among Trainee Adult Educators in University of Port Harcourt, British Journal of Education 2(3) (2014) 74-81. DOI: https://doi.org/10.1017/CBO9781107415324.00 $\underline{4}$

[10] M. Guo, P. Bhattacharya, M. Yang, K. Qian, L. Yang, Learning mobile security with android security labware, in Special Interest Group on Computer Science Education Conference, Association for Computing Machinery, New York, pp. 675-80. DOI: https://doi.org/10.1145/2445196.2445394

[11]A. Elfeky, T. Masadeh, The Effect of Mobile Learning on Students' Achievement and Conversational Skills, International Journal of Higher Education 5(3) (2016) 20-31. DOI: https://doi.org/10.5430/ijhe.v5n3p20

[12] M. Shofa, I. Redhana, P.P Juniartina, Analisis Kebutuhan Pengembangan Media Pembelajaran IPA Berbasis Argument Mapping, Journal Pendidikan dan Pembelajaran Sains Indonesia 3(1) (2020) 31-40. DOI: http://dx.doi.org/10.23887/jppsi.v3i1.24620.g14 $\underline{920}$
[13] A. Szabo, N. Hastings, Using IT in The Undergraduate Classroom: Should We Replace The Blackboard with Power Point?, Computers and Education 35(35) (2000) 175-187. DOI: https://doi.org/10.1016/S0360-1315(00)00030-0

[14] R. Bartsch, K. Cobern, Effectiveness of Power Point Presentations in Lectures, Computers and Education 41(1) (2003) 77-86. DOI: https://doi.org/10.1016/S0360-1315(03)00027-7 